$\begin{array}{ll}\text { Abstracta Iranica } & \begin{array}{l}\text { Abstracta Iranica } \\ \text { Revue bibliographique pour le domaine irano-aryen }\end{array} \\ & \text { Volume } \mathbf{3 7 - 3 8 - 3 9} \text { | } 2018 \\ \text { Comptes rendus des publications de 2014-2016 }\end{array}$

\title{
Marie-Catherine Rey, Huei-Chung Tsao (eds.). Jade: Des empereurs à l'art déco / Jade: From Emperors to Art Deco
}

\section{Yuka Kadoi}

\section{(2) OpenEdition \\ 1 Journals}

Electronic version

URL: http://journals.openedition.org/abstractairanica/43183

DOI: $10.4000 / a b s t r a c t a i r a n i c a .43183$

ISBN: 1961-960X

ISSN: 1961-960X

Publisher:

CNRS (UMR 7528 Mondes iraniens et indiens), Éditions de l'IFRI

\section{Electronic reference}

Yuka Kadoi, « Marie-Catherine Rey, Huei-Chung Tsao (eds.). Jade: Des empereurs à l'art déco / Jade: From Emperors to Art Deco », Abstracta Iranica [Online], Volume 37-38-39| 2018, document 9, Online since 30 December 2018, connection on 28 September 2020. URL : http://journals.openedition.org/ abstractairanica/43183; DOI : https://doi.org/10.4000/abstractairanica.43183

This text was automatically generated on 28 September 2020.

Tous droits réservés 


\title{
Marie-Catherine Rey, Huei-Chung Tsao (eds.). Jade: Des empereurs à l'art déco / Jade: From Emperors to Art Deco
}

\author{
Yuka Kadoi
}

\section{REFERENCES}

Marie-Catherine Rey, Huei-Chung Tsao (eds.). Jade: Des empereurs à l'art déco / Jade: From Emperors to Art Deco. Somogy Editions d'art \& musée national des arts asiatiques Guimet : Paris, 2016 (French version) /2017(English version), 288 p., 277 ill.

1 This beautifully illustrated volume has been published to accompany an exhibition on the arts of jade, organised jointly by the Musée National des Arts Asiatiques - Guimet in Paris and the National Palace Museum in Taipei in autumn 2016 - winter 2017. Showcasing more than 200 pieces drawn from not only the Chinese imperial collection but also local French collections, the exhibition demonstrates the significance of jade culture across Eurasia from ancient to modern times. Although jade is closely associated with the history of Chinese art, the major source of nephrite gemstone comes from Central Asia, notably Khotan, a major oasis town in southwestern Xinjiang. In addition, jade is a key material for the understanding of cross-cultural consumption in the Persian cultural lands, particularly among the Timurids and the Mughals. The volume consists of several essays, mostly written by Chinese art experts, yet the second half of the book provides useful pieces of information for Persian art experts: in an essay on the arts of jade from China and elsewhere, the number of relatively unknown jade objects from French collections, such as those from the Muséum national d'Histoire naturelle (cat. nos. 169, 177 and 180), catch the attention of experts and non-experts alike. Of particular note is the dragon-handled jug (cat. no. 177) - a classical type of Timurid jade art that entered the French royal collection as early as the early 1680 s and eventually the Museum of Natural History, shortly after its official foundation in 1793. Other noteworthy entries are on Chinese jade objects worked in the Indian style, called 
Hindustan (cat. nos. 197 and 198). The highlight of this volume, however, lies in the impact of jade on Art Deco jewellery, as attested by the magnificent presentation of the Cartier collection (see: pp. 248-273). It is widely known that anything "Oriental" encompassing Egypt, India and East Asia - provided an essential source of inspiration for Cartier. Yet this episode reminds us of the pivotal role of French jewellers in the formation of Persian art collections during the early $20^{\text {th }}$ century. Louis J. Cartier (1875-1942), grandson of the founder of the jewellery firm, was an avid collector of Persian illuminated and illustrated manuscripts.

\section{AUTHORS}

\section{YUKA KADOI}

University of Edinburgh 